Volume 8

Number 2 Student Articles Edition

Article 5

2-16-2022

\title{
Is a Website Subject to Title III of the ADA: Why the Text Applies to Only Websites "Of" a Place of Public Accommodation
}

Trevor Paul

Texas A\&M University School of Law (Student), tjp257@tamu.edu

Follow this and additional works at: https://scholarship.law.tamu.edu/journal-of-property-law

Part of the Disability Law Commons, Internet Law Commons, and the Property Law and Real Estate Commons

\section{Recommended Citation}

Trevor Paul, Is a Website Subject to Title III of the ADA: Why the Text Applies to Only Websites "Of" a Place of Public Accommodation, 8 Tex. A\&M J. Prop. L. 179 (2022).

Available at: https://doi.org/10.37419/JPL.V8.I2.5

This Notes \& Comments is brought to you for free and open access by Texas A\&M Law Scholarship. It has been accepted for inclusion in Texas A\&M Journal of Property Law by an authorized editor of Texas A\&M Law Scholarship. For more information, please contact aretteen@law.tamu.edu. 


\title{
IS A Website SubJECT TO TITLE III OF THE ADA: WHY THE TEXT APPLIES TO ONLY WEBSITES "Of" A Place OF Public ACCOMMOdation
}

\author{
Trevor Paul \\ Abstract
}

Title III of the Americans with Disabilities Act ("ADA") prohibits discrimination involving the "goods, services, facilities, privileges, advantages, or accommodations of any place of public accommodation." The ADA lists examples that qualify as "public accommodations," but it does not define the word "place." As a result, the circuit courts since 1995 have been split over whether a "place of public accommodation" is limited to a physical place. Courts have recently addressed whether websites are subject to Title III and have relied primarily on precedent on the interpretation of a "place of public accommodation." District courts within the Minority Approach have consistently held that a website is a "place of public accommodation." In contrast, the Ninth and Eleventh Circuits have held that a website is not a "place of public accommodation" and thus, not subject to Title III. Oddly enough, no court has held that a website is a "service," "privilege," or "advantage" of a "place of public accommodation." This Comment urges courts to subject Title III to only websites "of" a "place of public accommodation."

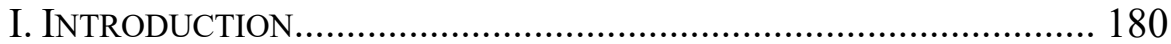

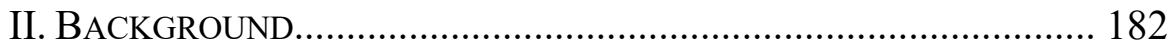

A. Enacting the ADA..................................................... 182

B. Title III of the ADA ................................................... 183

DOI: https://doi.org/10.37419/JPL.V8.I2.5

${ }^{\dagger}$ Trevor J. Paul is a J.D. Candidate at Texas A\&M University School of Law, Class of 2022. The Author would like to thank Professor Peter Reilly for serving as his faculty advisor and offering insight and guidance throughout the writing process. The Author would also like to thank his Note and Comment Editor, Annie Counts, for her immense support and feedback. Finally, the Author would like to thank his family and friends for their support and encouragement. 
C. Department of Justice ................................................. 184

III. A TEXTUAL BREAKDOWN OF TITLE III..................................... 186

A. Place of Public Accommodation ...................................... 188

1. The Minority Approach ........................................... 188

2. The Majority Approach ........................................... 189

B. Goods or Services "of" a Place of Public Accommodation .......................................................... 191

1. The Majority Approach ........................................... 191

2. The Second Circuit ................................................ 192

IV. Circuit COURTS Fail to Understand The Four Distinct

PORTIONS OF THE TEXT .......................................................... 193

A. Public Accommodation vs. Place of Public Accommodation......

B. Place of Public Accommodation vs. Service of a Place of

Public Accommodation.................................................. 194

V. COURTS' APPLICATION OF TITLE III TO WeBsites ......................... 197

A. The Eleventh Circuit..................................................... 198

B. The Ninth Circuit ......................................................... 199

C. District Courts Within the Minority Approach.................. 200

VI. WeBSiTES “OF” A Place OF PUBLIC ACCOMMODATION SHOULD

BE SUBJECT TO TITLE III .................................................... 202

A. Websites Are Not a Place of Public Accommodation .... 202

1. Faulty Circuit Court Precedent ................................. 203

2. Legislative History.................................................. 204

3. DOJ Guidance..................................................... 206

B. Certain Websites are a "Service," "Privilege," or

"Advantage" of a Place of Public Accommodation..... 207

1. Websites Are a "Service," "Privilege," or "Advantage" for Purposes of Title III ........................................ 207

2. Only Websites "Of” a Place of Public Accommodation

Should be Subject to Title III ................................. 209

VII. CONCLUSION.................................................................... 210

\section{INTRODUCTION}

While people increasingly rely on the internet, social media, online shopping, and web-based services, millions of disabled Americans continue to struggle with accessing these services. ${ }^{1}$ As a result, website accessibility lawsuits filed in federal courts have steadily

1. Monica Anderson \& Andrew Perrin, Disabled Americans are Less Likely to Use Technology, PEw RSCH. CTR. (Apr. 7, 2017), https://www.pewresearch.org/fact -tank/2017/04/07/disabled-americans-are-less-likely-to-use-technology/ [https:/ /perma.cc/X5QA-MU5Q]. 
increased from 814 in 2017 to more than 2,523 in $2020 .^{2}$ These lawsuits involve Title III of the ADA, ${ }^{3}$ which was enacted just one year before websites went public, ${ }^{4}$ and thus does not address whether websites or web-based services are subject to Title III.

Title III prohibits discrimination involving the "goods, services, facilities, privileges, advantages, or accommodations of any place of public accommodation." "Title III provides twelve categories of private entities that qualify as "public accommodations," such as hotels, restaurants, grocery stores, and many others, but it does not define the word "place." Thus, Title III leaves the first two words of a "place of public accommodation" open to interpretation by the courts. As a result, the circuit courts are split on whether a "place of public accommodation" is limited to a physical place. ${ }^{7}$

The Majority Approach adopted by the Third, Fifth, Sixth, Ninth, and Eleventh Circuits interprets "places of public accommodation" to apply only to physical locations and require a sufficient nexus between the goods or services complained of and an actual physical place. ${ }^{8}$ In contrast, the Minority Approach, adopted by First and Seventh Circuits, holds that a "place of public accommodation" is not limited to a physical place. ${ }^{9}$ This circuit split over the physical nature of a "place of public accommodation" has historically had little practical

2. Kristina M. Launey \& Minh N. Vu, Federal Website Accessibility Lawsuits Increased in 2020 Despite Mid-Year Pandemic Lull, SEYFARTH SHAw LLP: ADA TitLE III NEws \& INSIGHTS (Apr. 28, 2021), https://www.adatitleiii.com/2021/04 /federal-website-accessibility-lawsuits-increased-in-2020-despite-mid-year-pandemic-lull/ [https://perma.cc/VV9U-L54K].

3. Id.

4. Major Dan, February 26, 1991: When Did the Internet Go Public? (First Web Browser), Hist. \& HeADlines (Feb. 26, 2018), https://www.historyandheadlines.com/february-26-1991-internet-go-public-first-web-browser/ [https:/ /perma.cc/A6QJ-WQHE].

5. 42 U.S.C. $\S 12182(\mathrm{a})$.

6. 42 U.S.C. $\S 12181(7)$.

7. Compare Carparts Distrib. Ctr., Inc. v. Auto. Wholesaler's Ass'n of New Eng., Inc., 37 F.3d 12, 19-20 (1st Cir. 1994) and Morgan v. Joint Admin. Bd., 268 F.3d 456, 459 (7th Cir. 2001), with Ford v. Schering-Plough Corp., 145 F.3d 601, 612-14 (3d Cir. 1998), Magee v. Coca-Cola Refreshments USA, Inc., 833 F.3d 530, 531-36 (5th Cir. 2016), Parker v. Metro. Life Ins. Co., 121 F.3d 1006, 1010-15 (6th Cir. 1997), Weyer v. Twentieth Century Fox Film Corp., 198 F.3d 1104, 1113-14 (9th Cir. 2000), and Rendon v. Valleycrest Prods., Ltd., 294 F.3d 1279, 1280-81 (11th Cir. 2002).

8. Ford, 145 F.3d at 612-14; Magee, 833 F.3d at 532-36; Parker, 121 F.3d at 1010-14; Weyer, 198 F.3d at 1113-15; Rendon, 294 F.3d at 1284-85 n. 8.

9. Carparts Distrib. Ctr., Inc., 37 F.3d at 18-20; Morgan, 268 F.3d at 459. 
effect on the outcome of Title III lawsuits. But recently, courts considering websites, mobile applications, and web-based services (hereinafter "websites") under Title III have treated this circuit split over a "place of public accommodation" as determinative of whether websites are subject to Title III liability. ${ }^{10}$

While the larger issue is how websites comply with Title III, this Comment seeks only to analyze if Title III applies to a website. This Comment endorses the Ninth and Eleventh Circuits' interpretation that a website itself is not a "place of public accommodation" but advocates that courts should not limit their analysis to only that portion of the text. ${ }^{11}$ Rather, courts should also consider whether a website is a "service," "privilege," or "advantage" of a "place of public accommodation." 12 To reach this conclusion, Part II will provide background of Title III, including an overview of the ADA and the scope of Title III. ${ }^{13}$ Part III will then provide a textual breakdown of the caselaw based on the four parts of Title III, ${ }^{14}$ and Part IV will explain how courts have failed to understand these parts. ${ }^{15}$ Part V provides an overview of how courts have applied Title III to websites. ${ }^{16}$ Finally, Part VI will explain why only websites "of" a "place of public accommodation" should be subject to Title III. ${ }^{17}$

\section{BACKGROUND}

\section{A. Enacting the ADA}

While the Civil Rights Movement of the 1960s made significant progress toward protecting the rights of minorities and women, the rights of individuals with disabilities were not protected until much later. ${ }^{18}$ Discrimination against individuals with disabilities was not addressed until 1973 when Section 504 of the 1973 Rehabilitation Act was enacted, which banned federal funding recipients from

10. Carparts Distrib. Ctr., Inc., 37 F.3d at 18-20; Morgan, 268 F.3d at 459; 12182(a).

11. See infra Part V-VI.

12. See infra Part VI.

13. See infra Part II.

14. See infra Part III.

15. See infra Part IV.

16. See infra Part V.

17. See infra Part VI.

18. History of the ADA, MID-ATL. ADA CTR., http://www.adainfo.org/content /history-ada [https://perma.cc/H8DL-B64B]. 
discriminating on the basis of disability. ${ }^{19}$ Although the Rehabilitation Act was a step toward equal rights for disabled Americans, the Act did not protect individuals with disabilities in areas such as employment, public accommodation, and transportation. ${ }^{20}$

Yet in 1990, President George H.W. Bush signed the ADA into law and established "the world's first comprehensive declaration of equality for people with disabilities." ${ }^{21}$ Modeled after the Civil Rights Act of 1964, which made discrimination based on race, religion, sex, and national origin illegal, ${ }^{22}$ the ADA afforded similar protections for those with disabilities. ${ }^{23}$ In particular, the ADA prohibits discrimination against individuals with disabilities in important areas of life, such as: employment (Title I), public services (Title II), and places of public accommodation (Title III). ${ }^{24}$

\section{B. Title III of the ADA}

Title III of the ADA states that "[n]o individual shall be discriminated against on the basis of disability in the full and equal enjoyment of the goods, services, facilities, privileges, advantages, or accommodations of any place of public accommodation by any person who owns, leases (or leases to), or operates a place of public accommodation." 25 The ADA does not define the word "place," but it does list twelve categories of private entities that qualify as "public accommodations." ${ }^{26}$ These twelve categories are found in Section 12181(7) and are as follows:

a) an inn, hotel, motel, or other place of lodging;

b) a restaurant, bar, or other establishment serving food or drink;

c) a motion picture house, theater, concert hall, stadium, or other place of exhibition or entertainment;

19. $I d$

20. Id.

21. Laura Wolk, Note, Equal Access in Cyberspace: On Bridging the Digital Divide in Public Accommodations Coverage Through Amendment to the Americans with Disabilities Act, 91 Notre DAME L. REV. 447, 447 (2015) (internal quotation marks omitted) (quoting Remarks on Signing the Americans with Disabilities Act of 1990, 2 Pub. Papers 1068 (July 26, 1990)).

22. See Civil Rights Act of 1991, S.J. Res. 102d Cong. $\S 3$ (1991); 42 U.S.C.S. $\S 2000(\mathrm{e})$.

23. Americans with Disabilities Act of 1990, 42 U.S.C. $\S \S 12101-12213$.

24. PGA Tour, Inc. v. Martin, 532 U.S. 661, 675 (2001).

25. Americans with Disabilities Act of 1990, 42 U.S.C. $\$ 12182(a)$.

26. $\S \S 12181(7), 12182(a)$. 
d) an auditorium, convention center, lecture hall, or other place of public gathering;

e) a bakery, grocery store, clothing store, hardware store, shopping center, or other sales or retail establishment;

f) a laundromat, dry-cleaner, bank, barber shop, beauty shop, travel service, shoe repair service, funeral parlor, gas station, office of an accountant or lawyer, pharmacy, insurance office, professional office of a health care provider, hospital, or other service establishment;

g) a terminal, depot, or other station used for specified public transportation;

h) a museum, library, gallery, or other place of public display or collection;

i) a park, zoo, amusement park, or other place of recreation;

j) a nursery, elementary, secondary, undergraduate, or postgraduate private school, or other place of education;

k) a day care center, senior citizen center, homeless shelter, food bank, adoption agency, or other social service center establishment; and

1) a gymnasium, health spa, bowling alley, golf course, or other place of exercise or recreation. ${ }^{27}$

Notably, Section 12181(7) does not mention websites, but it does include broad catch-all language in each category. ${ }^{28}$ In addition, these twelve categories pertain only to "public accommodations." Thus, even if an entity's operations fall within one of the twelve categories above, Title III only applies to "places of" those operations. ${ }^{29}$ Title III provides additional specific requirements, but this Comment focuses on whether a website is subject to Title III liability.

\section{Department of Justice}

The ADA authorizes the Attorney General to issue implementing regulations and guidelines to aid in the interpretation and enforcement of Title III. ${ }^{30}$ Under this authority, the Department of Justice ("DOJ"), via the Attorney General, defined a "place of public accommodation" to include any "facility operated by a private entity whose operations affect commerce and fall within at least one of" the twelve categories provided in the regulations. ${ }^{31}$ Although the twelve categories provided by the regulations are virtually identical to those offered

27. § 12181(7).

28. $I d$.

29. § 12182(a).

30. $\S 12186(\mathrm{~b})$.

31. 28 C.F.R. $\S 36.104$ (2020). 
in Section 12181(7), the regulations define a "place" as a "facility," which in turn is defined as "all or any portion of buildings, structures, sites, complexes, equipment, rolling stock or other conveyances, roads, walks, passageways, parking lots, or other real or personal property, including the site where the building, property, structure, or equipment is located." 32

In 1996, the DOJ released its position on the applicability of the ADA to websites, stating that "places of public accommodation" with websites must ensure that their websites are accessible. ${ }^{33}$ But it was not until 2010 that the DOJ proposed a rule to apply Title III of the ADA to websites regardless of their connection to a "place of public accommodation." 34 In 2017, the Trump Administration, however, added the proposed rule to a list of "inactive" regulatory actions, ${ }^{35}$ and the DOJ later withdrew the proposal. ${ }^{36}$

Shortly after the DOJ withdrew the proposed rule, the DOJ filed an amicus brief with the U.S. Supreme Court supporting the Fifth Circuit's holding in Magee v. Coca-Cola Refreshments USA, Inc. that Coca-Cola's vending machines were not "places of public accommodation." "In its amicus brief, the DOJ stated that vending machines are not "places of public accommodation," but that "questions concerning Title III's application to non-physical establishments-including websites or digital services-may someday warrant this Court's attention." ${ }^{38}$ Despite the DOJ's refusal to take a position in its

32. Id.

33. See Letter from Deval L. Patrick, Assistant Att'y Gen. of the U.S., Dep't of Just., C.R. Div., to Tom Harkin, U.S. Sen., (Sept. 9, 1996), https://www.justice.gov /sites/default/files/crt/legacy/2010/12/15/tal712.txt [https://perma.cc/B8B8-9TN8].

34. Nondiscrimination on the Basis of Disability; Accessibility of Web Information and Services of State and Local Government Entities and Public Accommodations, 75 Fed. Reg. 43460 (July 26, 2010) (to be codified at 28 C.F.R. pts. 35-36).

35. U.S. Dep't of Just., 2017 Inactive Actions, REGINFO https://www.reginfo.gov/public/jsp/eAgenda/InactiveRINs_2017_Agenda_Update.pdf [https://perma.cc/6DGS-X3DN].

36. Nondiscrimination on the Basis of Disability; Notice of Withdrawal of Four Previously Announced Rulemaking Actions, 75 Fed. Reg. 43460 (Dec. 26, 2017) (to be codified at 28 C.F.R. pts. 35-36); Kristina M. Launey \& Minh N. Vu, Federal Website Accessibility Lawsuits Increased in 2020 Despite Mid-Year Pandemic Lull, SeYfarth Shaw LLP: ADA TITLE III News \& Insights (Apr. 28, 2021), https:/ /www.adatitleiii.com/2021/04/federal-website-accessibility-lawsuits-increased-in2020-despite-mid-year-pandemic-lull/ [https://perma.cc/VV9U-L54K].

37. Brief for the U.S. as Amicus Curiae at 5, Magee v. Coca-Cola Refreshments USA, Inc., 138 S. Ct. 55 (2017) (No. 16-668).

38. Id. at 22 . 
amicus brief on Title III's application to websites, the DOJ appeared to change its tune the next year when members of Congress requested clarity on "unresolved questions about the applicability of the ADA to websites," which have "created a liability hazard that directly affects businesses in our states ...."39 The DOJ responded that if a "place of public accommodation" has a website, then the website is subject to liability under Title III. ${ }^{40}$

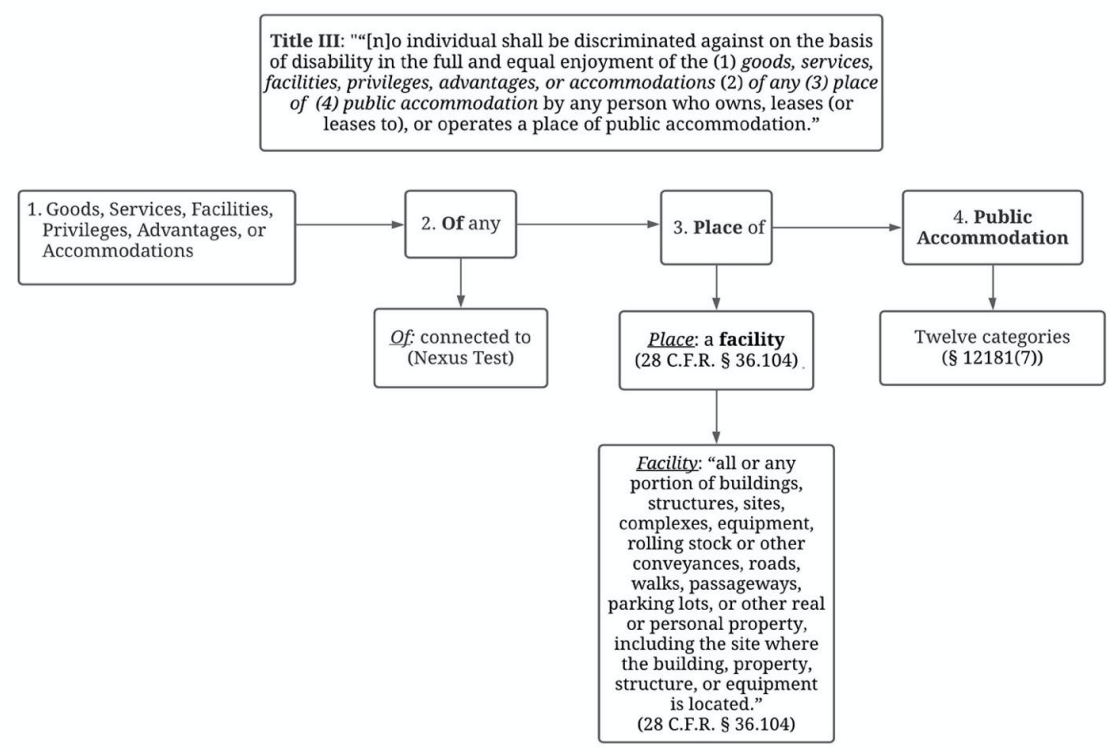

\section{A TEXTUAL BREAKDOWN OF TITLE III}

As depicted above, the text of Title III can be broken into four portions: (1) "goods, services, facilities, privileges, advantages, or accommodations"; (2) "of any"; (3) "place of"; and (4) "public accommodation." A review of Title III caselaw reveals that courts do not understand these four distinct portions. ${ }^{41}$ For that reason, the basis of

39. Letter from Members of Cong. to Jeff Sessions, Att'y Gen. of the U.S., Dep't of Just. (June 20, 2018), https://www.adatitleiii.com/wp-content/uploads/sites/121 /2018/06/ADA-Final-003.pdf [https://perma.cc/8ER3-WXML].

40. Letter from Stephen E. Boyd, Assistant Att'y Gen. of the U.S. Dep't of Just., to Ted Budd, U.S. H.R. (Sept. 25, 2018), https://www.adatitleiii.com/wp-content /uploads/sites/121/2018/10/DOJ-letter-to-congress.pdf [https://perma.cc/W8KAKNJM].

41. See infra Part IV. 
Title III caselaw is not different interpretations of the same words but rather on the selection or conflation of these four portions. ${ }^{42}$

The first example of this involves the circuit split on a "place of public accommodation," which has two parts: (1) the word "place" and (2) the twelve "public accommodation" categories. ${ }^{43}$ The Minority Approach, adopted by the First and Seventh Circuits, holds that a "place of public accommodation" is not limited to a physical place based on the twelve "public accommodation" categories, the services of an entity, and the ADA's purpose. ${ }^{44}$ In contrast, the Majority Approach, adopted by the Third, Fifth, Sixth, Ninth, and Eleventh Circuits, interprets "places of public accommodation" to apply only to physical locations based on the twelve "public accommodation" categories and the word "place." 45 In sum, the Minority Approach ignores the first portion of a "place of public accommodation"_- "place of"while the Majority Approach does not.

The second example concerns whether the goods or services are "of" a place of public accommodation. ${ }^{46}$ The Majority Approach and the Second Circuit apply the Nexus Test, which essentially interprets "of" to mean a connection. In effect, the Nexus Test requires a sufficient nexus or connection between the goods or services complained of and a "place of public accommodation." 47 Courts have not articulated precisely what that connection is. But, in terms of websites, courts have found a sufficient connection between a website and a "place of public accommodation" if a website includes things such as a store locator or the option to purchase gift cards. ${ }^{48}$

42. See infra Part IV.

43. See generally 42 U.S.C. § 12182(a) (2021); Carparts Distrib. Ctr., Inc. v. Auto. Wholesaler's Ass'n of New Eng., Inc., 37 F.3d 12, 18-20 (1st Cir. 1994); Morgan v. Joint Admin. Bd., 268 F.3d 456, 459 (7th Cir. 2001); Ford v. ScheringPlough Corp., 145 F.3d 601, 612-13 (3d Cir. 1998); Magee v. Coca-Cola Refreshments USA, Inc., 833 F.3d 530, 532-35 (5th Cir. 2016); Parker v. Metro. Life Ins. Co., 121 F.3d 1006, 1010-14 (6th Cir. 1997); Weyer v. Twentieth Century Fox Film Corp., 198 F.3d 1104, 1113-15 (9th Cir. 2000); Rendon v. Valleycrest Prods., Ltd., 294 F.3d 1279, 1280-81 (11th Cir. 2002).

44. Carparts Distrib. Ctr., Inc., 37 F.3d at 18-20; Morgan, 268 F.3d at 459.

45. Ford, 145 F.3d at 612-14; Magee, 833 F.3d at 532-36; Parker, 121 F.3d at 1010-15; Weyer, 198 F.3d at 1113-15; Rendon, 294 F.3d at 1281.

46. Pallozzi v. Allstate Life Ins. Co, 198 F.3d 28, 31-33 (2nd Cir. 1999); Ford, 145 F.3d at 612-14; Parker, 121 F.3d at 1011; Weyer, 198 F.3d at 1113-15; Rendon, 294 F.3d at 1284.

47. Parker, 121 F.3d at 1011.

48. Robles v. Domino's Pizza, LLC, 913 F.3d 898, 905-06 (9th Cir. 2019); Haynes v. Dunkin’ Donuts, LLC, 741 F. App'x 752, 753-54 (11th Cir. 2018). 


\section{A. Place of Public Accommodation}

\section{The Minority Approach}

The First and Seventh Circuits have interpreted a "place of public accommodation" to extend beyond physical places based on the twelve "public accommodation" categories, the services of an entity, and the ADA's purpose. ${ }^{49}$ The First Circuit in Carparts was the first to hold that a "place of public accommodation" is not limited to a physical place. ${ }^{50}$ In support, the court first pointed to the inclusion of the words "travel service" and "service establishment" in the list of "public accommodations." ${ }^{51}$ According to the First Circuit, a "travel service" is not a physical place because "[m]any travel services conduct business by telephone or correspondence without requiring their customers to enter an office in order to obtain their services." 52 The court also noted that a "service establishment" includes providers of services that do not require a person to physically enter an actual physical structure. ${ }^{53}$ Put differently, the court reasoned that a "place of public accommodation" is not limited to a physical place because the services of many entities, whose operations fall within one of the twelve "public accommodation" categories, are not limited to a physical place. The court found that to conclude otherwise "would severely frustrate Congress's intent that individuals with disabilities fully enjoy the goods, services, privileges and advantages, available indiscriminately to other members of the general public." 54

Similarly, the Seventh Circuit in Morgan v. Joint Administration Board held that a "place of public accommodation" is not limited to a physical place for similar reasons ${ }^{55}$ But unlike the First Circuit in Carparts, the court did not specifically reference any examples in the twelve "public accommodation" categories. ${ }^{56}$ The court instead relied on the other two reasons mentioned in Carparts - the services of an entity and the ADA's purpose - in stating that "the site of the sale is irrelevant to Congress's goal of granting the disabled equal access to

49. Carparts Distrib. Ctr., Inc., 37 F.3d at 18-20; Morgan, 268 F.3d at 459.

50. Carparts Distrib. Ctr., Inc., 37 F.3d at 19.

51. Id.

52. Id.

53. Id.

54. $I d$. at 20.

55. Morgan v. Joint Admin. Bd., 268 F.3d 456, 459 (7th Cir. 2001).

56. $I d$. 
sellers of goods and services. What matters is that the good or service be offered to the public." 57 The First Circuit and the Seventh Circuit did not reference or attempt to interpret the word "place" and only looked at the twelve "public accommodation" categories when interpreting a "place of public accommodation." 58

\section{The Majority Approach}

While the Minority Approach looks only at the twelve "public accommodation" categories, the Majority Approach, adopted by the Third, Fifth, Sixth, Ninth, and Eleventh Circuits, interprets "places of public accommodation" to apply only to physical locations based on the twelve "public accommodation" categories and the word "place." ${ }^{59}$ In other words, the Majority Approach breaks a "place of public accommodation" into two parts: (1) a place and (2) public accommodation. The Sixth Circuit in Stoutenborough v. National Football League, Inc. was the first circuit court to hold that a "place of public accommodation" is limited to the word "place." 60 The court did not specifically state that a "place of public accommodation" is limited to a physical place, but, unlike the First Circuit, it highlighted the word "place." 61 The court reasoned that even if an entity's operations fell within one of the twelve "public accommodation" categories, the prohibitions are restricted to "places" of "public accommodation." 62 The court interpreted a "place" based on the DOJ's regulations that define a "place" as a "facility." 63

Shortly after Stouenborough, the Sixth Circuit in Parker v. Metropolitan Life Insurance Co. addressed the same issue but differed with the First Circuit's holding in Carparts based on the twelve "public accommodation" categories rather than the word "place." ${ }^{44}$ In

57. $I d$.

58. Carparts Distrib. Ctr., Inc., 37 F.3d at 18-20; Morgan, 268 F.3d at 459.

59. Ford v. Schering-Plough Corp., 145 F.3d 601, 612-13 (3d Cir. 1998); Magee v. Coca-Cola Refreshments USA, Inc., 833 F.3d 530, 532-35 (5th Cir. 2016); Parker v. Metro. Life Ins. Co., 121 F.3d 1006, 1010-14 (6th Cir. 1997); Weyer v. Twentieth Century Fox Film Corp., 198 F.3d 1104, 1113-15 (9th Cir. 2000); Rendon v. Valleycrest Prods., Ltd., 294 F.3d 1279, 1282 (11th Cir. 2002).

60. Stoutenborough v. Nat'l Football League, Inc., 59 F.3d 580, 582-83 (6th Cir. 1995).

61. Id. at 583 .

62. $I d$.

63. Id. (quoting 28 C.F.R. $\S 36.104$ ).

64. Parker, 121 F.3d at 1011. 
Parker, the court reasoned that the First Circuit ignored the text of the statute and the principle of noscitur a sociis, ${ }^{65}$ which instructs that "a ... term is interpreted within the context of the accompanying words 'to avoid the giving of unintended breadth to the Acts of Congress." "66 The court reasoned that an "[o]ffice of an accountant or lawyer, insurance office, and professional office of a healthcare provider, in the context of the other terms listed, suggest a physical place where services may be obtained and nothing more." 67 The court added that "[t]o interpret these terms as permitting a place of accommodation to constitute something other than a physical place is to ignore the text of the statute and the principle of noscitur a sociis." ${ }^{\text {" }} 8$ For those reasons and because the twelve "public accommodation" categories are limited to physical places, the court held that a "place of public accommodation" is limited to a physical place. ${ }^{69}$

The Sixth Circuit's holding in Parker differs from the court's prior holding in Stoutenborough for two notable reasons. First, the court in Parker explicitly held that a "place of public accommodation" is limited to a physical place. ${ }^{70}$ The court in Stoutenborough may have implied that a "place of public accommodation" is limited to a physical place by referencing the DOJ's regulations defining a "place." But the court did not expressly state this position. Second, the court in Parker based its reasoning on the twelve "public accommodation" categories, while the court in Stoutenborough based its reasoning on the word "place."72 Later, the Third, Fifth, Ninth, and Eleventh Circuits followed the Sixth Circuit, holding that a "place of public accommodation" is limited to a physical place but did so based on the word "place" rather than the "public accommodation" categories. ${ }^{73}$

65. Id. at 1014 .

66. Id. (quoting Kurinsky v. United States, 33 F.3d 594, 597 (6th Cir. 1994)).

67. $I d$.

68. $I d$.

69. Id. at 1010.

70. $I d$.

71. Stoutenborough v. Nat'1 Football League, Inc., 59 F.3d 580, 583 (6th Cir. 1995).

72. Parker, 121 F.3d at 1011.

73. Ford v. Schering-Plough Corp., 145 F.3d 601, 612-14 (3d Cir. 1998); Magee v. Coca-Cola Refreshments USA, Inc., 833 F.3d 530, 532-36 (5th Cir. 2016); Weyer v. Twentieth Century Fox Film Corp., 198 F.3d 1104, 1113-15 (9th Cir. 2000); Rendon v. Valleycrest Prods., Ltd., 294 F.3d 1279, 1281 (11th Cir. 2002). 
B. Goods or Services "of" a Place of Public Accommodation

\section{The Majority Approach}

After determining whether there is a "place of public accommodation," the second step of the Majority Approach is to determine whether the goods or services are "of" a "place of public accommodation." "74 To do so, the Majority Approach applies the Nexus Test, which requires a sufficient nexus between the goods or services complained of and a "place of public accommodation." 75 While courts have not explicitly stated that the word "of" is the statutory basis for the Nexus Test, it is fairly evident because the word "of" is between what is being complained of and a "place of public accommodation." 76

The Nexus Test first emerged in Stoutenborough, where the Sixth Circuit considered whether a television broadcast of a professional football game was a service of a "place of public accommodation." 77 Although the football stadiums were indeed a "place of public accommodation," the court reasoned that: (1) the broadcasts were not services or goods of the football stadiums $;{ }^{78}(2)$ that the plain meaning of Title III is that a "place of public accommodation" is a place; (3) and that "all of the services which the public accommodation offers, not all services which the lessor of the public accommodation offers, fall within the scope of Title III."79 In other words, the text regulates the goods and services of "places of public accommodation," not the goods and services of the entity. While the Sixth Circuit in Stoutenborough did not explicitly mention the term "nexus," the court made clear that there must be a connection between the service offered and the "place of public accommodation" for Title III to apply. ${ }^{80}$

74. Ford, 145 F.3d at 612-14; Parker, 121 F.3d at 1011; Weyer, 198 F.3d at 1113-15; Rendon, 294 F.3d at 1284.

75. Ford, 145 F.3d at 612-14; Parker, 121 F.3d at 1011; Weyer, 198 F.3d at 1113-15; Rendon, 294 F.3d at 1284.

76. Pallozzi v. Allstate Life Ins. Co., 198 F.3d 28, 31-33 (2nd Cir. 1999); Ford, 145 F.3d at 612-14; Parker, 121 F.3d at 1011; Weyer, 198 F.3d at 1113-15; Rendon, 294 F.3d at 1284.

77. See Stoutenborough v. Nat'l Football League, Inc., 59 F.3d 580 (6th Cir. 1995).

78. Id. at 583 .

79. Id.

80. See id. 
Two years after Stoutenborough, the term "nexus" emerged in the Sixth Circuit's holding in Parker. ${ }^{81}$ The court in Parker held that while the insurance office was a "place of public accommodation," the services that the plaintiff sought had "no nexus" to the insurance office because the plaintiff "did not access her policy from [an] insurance office" and instead "obtained her benefits through her employer." 82 Later, the Second, Third, Ninth, and Eleventh Circuits followed and adopted the Nexus Test in determining whether a good or service is "of" a "place of public accommodation." 83

\section{The Second Circuit}

The Second Circuit in Pallozzi also adopted the Nexus Test. But, unlike the Majority Approach, the court did not take an affirmative position on whether a "place of public accommodation" is limited to a physical place. ${ }^{84}$ The court relied on the First Circuit's holding in Carparts that limiting "Title III to physical structures ... would severely frustrate Congress's intent that individuals with disabilities fully enjoy the goods, services, privileges and advantages, available indiscriminately to other members of the general public." 85 According to the Second Circuit, however, the Sixth Circuit's holding in Parker and the Third Circuit's holding in Ford were not to the contrary. ${ }^{86}$ The court reasoned that while Parker and Ford held that a "place of public accommodation" is limited to a physical place, these cases did not hold that "full and equal enjoyment of the goods, [and] services ... of any place of public accommodation" is limited to only physical access to a "place of public accommodation." 87

Although the Second Circuit took no position on the circuit split, the court did articulate that services with a nexus to a "place of public accommodation" are not limited to physical access. ${ }^{88}$ The

81. Parker, 121 F.3d at 1011.

82. Id.

83. Pallozzi v. Allstate Life Ins. Co., 198 F.3d 28, 31-33 (2nd Cir. 1999); Ford v. Schering-Plough Corp., 145 F.3d 601, 612-14 (3d Cir. 1998); Weyer v. Twentieth Century Fox Film Corp., 198 F.3d 1104, 1113-15 (9th Cir. 2000); Rendon v. Valleycrest Prods., Ltd., 294 F.3d 1279, 1284 n.8 (11th Cir. 2002).

84. Pallozzi, 198 F.3d at 31-33.

85. Id. at $32-33$.

86. Id. at 32 n.3.

87. Id.

88. Id. 
court's holding helped clarify that the Nexus Test involves the word "of" and that services "of" a "place of public accommodation" are not limited to physical access, even if a "place of public accommodation" is limited to a physical place. ${ }^{89}$

\section{Circuit Courts Fail to Understand The Four Distinct PORTIONS OF THE TEXT}

\section{A. Public Accommodation vs. Place of Public Accommodation}

The most common mistake made by courts on both sides of the circuit split is their failure to recognize that a "place of public accommodation" must be a "place." "90 As mentioned above, Title III provides twelve categories that constitute a "public accommodation," not twelve categories that constitute a "place of public accommodation." Still, courts on both sides of the circuit split have glossed over the word "place" when interpreting a "place of public accommodation." 92 One example is the Sixth Circuit's incorrect holding in Parker only two years after the court's correct holding in Stoutenborough. In Parker, the Sixth Circuit, referring to Stoutenborough, stated: "As is evident by $\S 12187(7)$, a public accommodation is a physical place and this Court has previously so held." 93 But the court in Stoutenborough stated that "[f]irst, none of the defendants falls within any of the twelve 'public accommodation' categories identified in the statute. 42 U.S.C. $\S 12181(7)$. Also, the prohibitions of Title III are restricted to 'places' of public accommodation." 94 In other words, the court in Stoutenborough did not hold that a public accommodation is a limited place; the court held that Title III is "also ... restricted to 'places' of public accommodation." public accommodation" is limited to a physical place. While the Sixth Circuit's error in Parker has little practical relevance if a "public accommodation" is limited to a physical place, the Sixth Circuit's error highlights that even courts applying the Majority Approach fail to

89. Id. at 33 .

90. See Stoutenborough v. Nat'l Football League, Inc., 59 F.3d 580, 583 (6th Cir. 1995).

91. 42 U.S.C. $§ 12181(7)$.

92. Parker v. Metro. Life Ins. Co., 121 F.3d 1006, 1011 n.3 (6th Cir. 1997).

93. Id. at 1010-11.

94. Stoutenborough, 59 F.3d at 583 (emphasis added).

95. Id. 
understand their own precedent and the differences between the "public accommodation" categories and a "place of public accommodation."

Unlike courts within the Majority Approach that disregard the word "place," the Minority Approach's disregard of the word "place" is practically relevant because these courts hold that a "place of public accommodation" is not limited to a physical place. ${ }^{96}$ The First and Seventh Circuits hold that a "place of public accommodation" is not limited to a physical place based solely on the twelve "public accommodation" categories. ${ }^{97}$ As a result, any entity with operations that fall within one of the twelve "public accommodation" categories is subject to Title III liability. ${ }^{98}$ This mistake is fatal for businesses with websites. Now, district courts applying the Minority Approach have subjected websites to Title III only because the website falls within one of the twelve "public accommodation" categories. ${ }^{99}$

\section{B. Place of Public Accommodation vs. Service of a Place of Public Accommodation}

The Minority Approach not only sidesteps the word "place" when interpreting "place of public accommodation," but it also mistakenly fails to distinguish "places of public accommodation" from the "services" of a "place of public accommodation." 100 In essence, the Minority Approach interprets a "place of public accommodation" to mean a "service of public accommodation."

For example, the First Circuit in Carparts held that a "place of public accommodation" is not limited to a physical place because places of public accommodation "conduct business by telephone or correspondence without requiring their customers to enter an office in order to obtain their services." by other means, however, constitutes "services of" a "place of public

96. Carparts Distrib. Ctr., Inc. v. Auto. Wholesaler's Ass'n of New Eng., Inc., 37 F.3d 12, 18-20 (1st Cir. 1994); Morgan v. Joint Admin. Bd., 268 F.3d 456, 459 (7th Cir. 2001).

97. Carparts Distrib. Ctr., Inc., 37 F.3d at 19-20; Morgan, 268 F.3d at 459. 2012).

98. Nat'l Ass'n of the Deaf v. Netflix, Inc., 869 F. Supp. 2d 196, 201 (D. Mass.

99. See id. at 201-02.

100. See Carparts Distrib. Ctr., Inc., 37 F.3d at 18-20; see also Morgan v. Joint Admin. Bd., 268 F.3d 456, 459 (7th Cir. 2001).

101. Carparts Distrib. Ctr., Inc., 37 F.3d at 19. 
accommodation," not "places of public accommodation."102 Thus, while the court's holding is that a "place of public accommodation" is not limited to a physical place, the court's reasoning stems from the services of a "place of public accommodation." 103 The Seventh Circuit in Morgan committed a similar mistake:

The defendant asks us to interpret "public accommodation" literally, as denoting a physical site, such as a store or a hotel, but we have already rejected that interpretation ... The site of the sale is irrelevant to Congress's goal of granting the disabled equal access to sellers of goods and services. What matters is that the good or service be offered to the public. ${ }^{104}$

The goods or services of an entity should have no bearing on whether a "place of public accommodation" is limited to a physical place. The only bearing the goods and services of an entity should have is when determining whether an entity's operations fall within one of the twelve "public accommodation" categories. The text regulates the goods and services "of any place of public accommodation," not the goods or services of any business. ${ }^{105}$ The Majority Approach is not that services of a "place of public accommodation" are limited to a physical place, only that a "place of public accommodation" is limited to a physical place. ${ }^{106}$ Suppose the alleged discrimination turns on services of a "place of public accommodation." In that case, the Majority Approach will apply the Nexus Test, which is not limited to discrimination based on the physical nature of goods and services of the "place of public accommodation." 107

But even courts that follow the Majority Approach fail to understand the difference between a place of public accommodation and services of a "place of public accommodation." 108 For example, the

102. 42 U.S.C. $\S 12182(a)$.

103. See Carparts Distrib. Ctr., Inc., 37 F.3d at 20; 42 U.S.C. § 12182(a).

104. Morgan, 268 F.3d at 459.

105. § 12182(a).

106. See generally Ford v. Schering-Plough Corp., 145 F.3d 601, 612-14 (3d Cir. 1998); Magee v. Coca-Cola Refreshments USA, Inc., 833 F.3d 530, 533-35 (5th Cir. 2016); Parker v. Metro. Life Ins. Co., 121 F.3d 1006, 1010-14 (6th Cir. 1997); Weyer v. Twentieth Century Fox Film Corp., 198 F.3d 1104, 1113-15 (9th Cir. 1999); Rendon v. Valleycrest Prods., Ltd., 294 F.3d 1279, 1284 (11th Cir. 2002).

107. See generally Pallozzi v. Allstate Life Ins., Co., 198 F.3d 28, 31-33 (2d Cir. 1999); Ford, 145 F.3d at 612-14; Parker, 121 F.3d at 1011; Weyer, 198 F.3d at 1115; Rendon, 294 F.3d at 1284.

108. Magee, 833 F.3d at 532-36; Earll v. eBay, Inc., 599 F. App'x 695, 695 (9th Cir. 2015). 
Fifth Circuit in Magee reasoned that the Second Circuit in Pallozzi interpreted a "place of public accommodation" to extend beyond a physical place. ${ }^{109}$ Yet the Second Circuit did not take an affirmative position on whether a "place of public accommodation" is limited to a physical place. ${ }^{110}$ The Second Circuit merely held that services of a "place of public accommodation" are not limited to physical access of the "place of public accommodation."111 In fact, the Second Circuit explained that its holding was not contrary to the Majority Approach: "[N]either Parker nor Ford held that Title III ensures only physical access to places of public accommodation. Their reasoning was that plaintiffs must have a nexus to a place of public accommodation in order to claim the protections of Title III." 112

The Ninth Circuit in Earll and Weyer committed the same mistake by 'interpret[ing] the term 'place of public accommodation' to require 'some connection between the good or service complained of and an actual physical place." 113 In Weyer, the court cited the Third and Sixth Circuits' holdings in Ford and Parker in support, ${ }^{114}$ but these cases clarify that the connection to the good or service is irrelevant to determine whether there is a "place of public accommodation." "In Ford and Parker, the courts concluded that an insurance office was a "place of public accommodation" but that there was no nexus between the goods and services complained of and the insurance office. ${ }^{116}$ To illustrate, the Sixth Circuit in Parker explained:

While we agree that an insurance office is a public accommodation as expressly set forth in $\S 12181(7)$, plaintiff did not seek the goods and services of an insurance office. Rather, Parker accessed a benefit plan provided by her private employer and issued by MetLife. A benefit plan offered by an employer is not a good offered by a place of public accommodation. ${ }^{117}$

109. Magee, 833 F.3d at 534 n.23.

110. Pallozzi, 198 F.3d at 31-33.

111. Id.

112. Id. at $32 \mathrm{n} .3$.

113. Earll, 599 F. App'x at 695 (quoting Weyer v. Twentieth Century Fox Film

Corp., 198 F.3d 1104, 1114 (9th Cir. 1999)).

114. Weyer, 198 F.3d at 1114-15.

115. Ford v. Schering-Plough Corp., 145 F.3d 601, 612-14 (3rd Cir. 1998); Par-

ker v. Metro. Life Ins. Co., 121 F.3d 1006, 1011 (6th Cir. 1997).

116. Ford, 145 F.3d at 612-14; Parker, 121 F.3d at 1011.

117. Parker, 121 F.3d at 1010. 
Because the plaintiff in Parker did not seek the goods or services of the insurance office does not mean that an insurance office is no longer a "place of public accommodation."" 18 Instead, the court in Parker merely stated that the plaintiff must seek the goods and services of the "place of public accommodation" for Title III to apply. ${ }^{119}$ Oddly enough, the Ninth Circuit in Weyer cited this exact paragraph as support. $^{120}$

The Ninth Circuit's mistake is just another example of how courts on both sides of the circuit split fail to understand the difference between a "place of public accommodation" and its services. This failure has implications for any entity's services, such as websites, cellphones, and emails, because those services are typically of the entity and not of a "place of public accommodation."121

\section{COURTS’ APPLICATION OF TITLE III TO WEBSITES}

Although websites have existed for more than 30 years, the Eleventh Circuit in 2018 was the first circuit to consider whether Title III applies to a website. ${ }^{122}$ The Ninth Circuit is the only other circuit court to address the issue. ${ }^{123}$ The Ninth and Eleventh Circuits, applying the Majority Approach, have held that a website itself is not a "place of public accommodation." "124 That said, the Ninth and Eleventh Circuits disagree about whether websites are free from Title III liability if there is a nexus between a website and a "place of public accommodation." 125 In 2018, the Eleventh Circuit, like the Ninth Circuit, applied the Nexus Test to websites. ${ }^{126}$ Yet in 2021, the Eleventh Circuit in Gil decided to go in a different direction by declining to adopt the Nexus Test and holding that websites are never subject to Title III liability because a website is not a "place of public

118. Id. at 1011 .

119. Id.

120. Weyer v. Twentieth Century Fox Film Corp., 198 F.3d 1104, 1115 (9th Cir. 2000).

121. See infra Part VI.

122. Haynes v. Dunkin' Donuts LLC, 741 Fed. App'x 752, 753-54 (11th Cir. 2018).

123. Robles v. Domino's Pizza, LLC, 913 F.3d 898, 905-06 (9th Cir. 2019).

124. Robles, 913 F.3d at 905-06; Gil v. Winn-Dixie Stores, Inc., 993 F.3d 1266, 1274-77 (11th Cir. 2021).

125. Compare Robles, 913 F.3d at 905-06, with Gil, 993 F.3d at 1278-81.

126. Haynes, 741 Fed. App'x at 753-54. 
accommodation."127 Unlike the Ninth and Eleventh Circuits, district courts within the First and Seventh Circuits have applied the Minority Approach, holding that a website itself is a "place of public accommodation." 128

\section{A. The Eleventh Circuit}

As noted above, the Eleventh Circuit in 2018 was the first to analyze whether Title III applies to a website. ${ }^{129}$ The court in Haynes held that because Dunkin' Donuts' website includes a store locator and allows customers to purchase gift cards, "the website is a service that facilitates the use of Dunkin' Donuts' shops, which are places of public accommodation." 130 The court relied on its precedent in Rendon, where the court held that the inaccessibility of a telephone selection process prevented the plaintiffs from accessing a privilege of the defendant's "place of public accommodation," a television studio. ${ }^{131}$ The court reasoned that:

[a]s much as the telephone selection process in Rendon prevented the plaintiffs in that case from accessing a privilege of that defendant's physical place of public accommodation, the alleged inaccessibility of Dunkin' Donuts' website denies Haynes access to the services of the shops that are available on Dunkin' Donuts' website, which includes the information about store locations and the ability to buy gift cards online. ${ }^{132}$

In essence, the court held that the store locator and gift cards are "services" of the physical stores, not that the website per se is a "service" of the physical stores. ${ }^{133}$ That said, since the court designated the opinion to be unpublished, it has no precedential value. ${ }^{134}$

127. Gil, 993 F.3d at $1274-81$.

128. Nat'1 Ass'n of the Deaf v. Netflix, Inc., 869 F. Supp. 2d 196, 201 (D. Mass. 2012); Access Now, Inc. v. Blue Apron, LLC, No. 17-cv-116-JL, 2017 WL 5186354, at *3 (D.N.H. Nov. 8, 2017); Wright v. Thread Experiment, LLC, No. 19 -cv-01423-TAB, 2021 WL 243604, at *2 (S.D. Ind. Jan. 22, 2021); Laufer v. Lily Pond LLC C Series, No. 20-cv-617, 2020 WL 7768011, at*3 (W.D. Wis. Dec. 30, 2020).

129. Haynes, $741 \mathrm{Fed}$. App'x at 753-54.

130. Id. at 754 (emphasis added).

131. Id.

132. Id. (emphasis added).

133. Id.

134. See Fed. R. APP. P. 32.1; see also 11TH CIR. R. 36-2. 
Despite the Eleventh Circuit's adoption of the Nexus Test in Haynes, the Eleventh Circuit in Gil rejected to follow the Nexus Test. ${ }^{135}$ First, the court held that a website is not a "place of public accommodation" based on the twelve "public accommodation" categories. ${ }^{136}$ The court then addressed whether the website otherwise violates Title III, specifically whether the inaccessibility of WinnDixie's website is "an 'intangible barrier' to accessing the goods, services, privileges, or advantages of Winn-Dixie's physical stores."137 The court held that Winn-Dixie's website is not an intangible barrier because it has limited functionality and is not the sole access point to accessing the goods and services of its physical stores. ${ }^{138}$ Finally, the court addressed Gil's argument that there is a nexus between WinnDixie's website and its physical stores. ${ }^{139}$ The court did not state whether such a nexus existed and ultimately declined to adopt the Nexus Test because the court found "no basis for it in statute or in [their] precedent." 140 Still, the court went to considerable length to distinguish the facts from those in Robles, where the Ninth Circuit adopted the Nexus Test. Ironically, the court in Gil did not mention or distinguish its holding from the court's holding in Haynes, which expressly adopted the Nexus Test. ${ }^{141}$

\section{B. The Ninth Circuit}

The Ninth Circuit in Robles held that there was a sufficient nexus between Domino's website and its physical restaurants because Domino's website included a store locator and allowed customers to order pizzas for delivery or in-store pickup. ${ }^{142}$ The court reasoned that "the alleged inaccessibility of Domino's website and app impedes access to the goods and services of its physical pizza franchises - which are places of public accommodation." "143 Unlike the Eleventh Circuit in Haynes, the court did not state that the store locator or order

135. Gil v. Winn-Dixie Stores, Inc., 993 F.3d 1266, 1281 (11th Cir. 2021).

136. Id. at 1277 .

137. Id. at 1278 .

138. Id. at 1279 .

139. Id. at 1281 .

140. Id.

141. See Gil, 993 F.3d at 1266; see also Haynes v. Dunkin' Donuts LLC, 741 F. App'x 752, 754 (11th Cir. 2018).

142. Robles v. Domino's Pizza, LLC, 913 F.3d 898, 905-06 (9th Cir. 2019).

143. Id. at 905 . 
functions were "services" of Domino's physical stores. ${ }^{144}$ But the court did state that the store locator and ordering functions established a "nexus between Domino's website and app and physical restaurants . ..."145 Thus, assuming that the court understood the textual basis of the Nexus Test, the court considered these portions of Domino's websites to be "services" of Domino's physical stores, even though the court did not explicitly say so.

\section{District Courts Within the Minority Approach}

While no circuit court has held that a website is a "place of public accommodation," district courts applying the Minority Approach have held that a website itself is a "place of public accommodation." "146 These courts have relied mainly on circuit court precedent that a "place of public accommodation" is not limited to a physical place based on the twelve "public accommodation" categories, the services of an entity, and the ADA's purpose. ${ }^{147}$ In terms of websites specifically, these courts have also relied on DOJ guidance on websites and the ADA's legislative history. ${ }^{148}$

Recently, two district courts within the First Circuit held that Netflix's video streaming website and Blue Apron's cooking website are "places of public accommodation." 149 In the first case, the district court in National Ass' $n$ of the Deaf held that Netflix's video streaming website is a "place of public accommodation." 150 The court reasoned that the First Circuit's binding precedent in Carparts "applies with equal force to services purchased over the internet, such as video programming offered through the Watch Instantly web site" because "[i]n

144. Id.

145. Id.

146. Nat'l Ass'n of the Deaf v. Netflix, Inc., 869 F. Supp. 2d 196, 201 (D. Mass. 2012); Access Now, Inc. v. Blue Apron, LLC, No. 17-cv-116-JL, 2017 WL 5186354, at *3 (D.N.H. Nov. 8, 2017); Wright v. Thread Experiment, LLC, No. 19 -cv-01423-TAB, 2021 WL 243604, at*2 (S.D. Ind. Jan. 22, 2021); Laufer v. Lily Pond LLC C Series, No. 20-cv-617, 2020 WL 7768011, at*3 (W.D. Wis. Dec. 30, 2020).

147. Carparts Distrib. Ctr., Inc. v. Auto. Wholesaler's Ass'n of New Eng., Inc., 37 F.3d 12, 18-20 (1st Cir. 1994); Morgan v. Joint Admin. Bd., 268 F.3d 456, 459 (7th Cir. 2001).

148. Nat'l Ass'n of the Deaf, 869 F. Supp. 2d at 201; Access Now, Inc., 2017 WL 5186354, at*3; Wright, 2021 WL 243604, at*3; Laufer, 2020 WL 7768011, at*4.

149. Nat'l Ass'n of the Deaf, 869 F. Supp. 2d at 200-02; Access Now, Inc., 2017 WL 5186354, at*3.

150. 869 F. Supp. 2d at 200-02. 
a society in which business is increasingly conducted online, excluding businesses that sell services through the internet from the ADA would 'run afoul of the purposes of the ADA and would severely frustrate Congress's intent .... "" 151 While the court determined that Netflix's video streaming services fell under several "public accommodation" categories, the court did not address how Netflix's video streaming services were a place. ${ }^{152}$ Even so, the court held that Netflix's video streaming service was a "place of public accommodation" because "the legislative history of the ADA makes clear that Congress intended the ADA to adapt to changes in technology." 153

In the second case, Access Now, Inc., the plaintiff sued the defendant, Blue Apron, for allegedly failing to make its cooking website compatible with screen reading technology. ${ }^{154}$ While the court held that Blue Apron's website was a "place of public accommodation," the court's reasoning differed slightly from the district court's holding in National Ass' $n$ of the Deaf. ${ }^{155}$ Rather than relying heavily on legislative history to support its holding, the court reasoned that while "Courts of Appeals differ on what constitutes a "public accommodation' in the website context, the First Circuit Court of Appeals appears to consider websites, standing alone, as public accommodations under circumstances such as these. That authority binds this court." 156 It is unclear to which case the court was referring to because it cited no circuit court case to support the proposition. ${ }^{157}$ The only First Circuit case that the district court cited was Carparts, which did not involve a website or discuss Title III's applicability to websites. ${ }^{158}$ Still, the court held that Blue Apron's website was a "place of public accommodation" based on the First Circuit's reasoning in Carparts. ${ }^{159}$

The district courts' holdings in National Ass' $n$ of the Deaf and Access Now, Inc. also follow holdings of district courts within the Seventh Circuit. ${ }^{160}$ For example, a district court within the Seventh Circuit

\footnotetext{
151. Id. at 200 (quoting Carparts Distrib. Ctr., Inc., 37 F.3d at 20).

152. Id. at 201 .

153. Id. at 200-01.

154. Access Now, Inc., 2017 WL 5186354, at*3-4.

155. Id. at *3.

156. Id.

157. $I d$.

158. $I d$.

159. Id.

160. Wright v. Thread Experiment, LLC, No. 19-cv-01423-TAB, 2021 WL 243604, at *3 (S.D. Ind. Jan. 22, 2021); Laufer v. Lily Pond LLC C Series, No. 20-
} 
recently held that a defendant's website was a "place of public accommodation" based on DOJ guidance, other district courts' holdings, and Seventh Circuit precedent. ${ }^{161}$ As for DOJ guidance, the court cited the DOJ's 2018 letter mentioned in Part II(C) and interpreted the letter to mean that the DOJ considers websites a "place of public accommodation." " 62 In terms of the holdings of other district courts, the court mentioned that "there is nonetheless significant momentum from district courts across the nation supporting an interpretation of the ADA which mandates such compliance, regardless of whether the website is associated with any physical store." 163 Like the district courts within the First Circuit and their reliance on circuit court precedent that did not involve websites, the court relied on the Seventh Circuit's holding in Morgan that also did not involve a website. ${ }^{164}$ In sum, district courts within both the First and Seventh Circuits rely mainly on circuit court precedent, legislative history, and DOJ guidance to support their holdings. ${ }^{165}$

\section{Websites “OF” A Place OF Public ACCOMMOdation Should BE SUBJECT TO TITLE III}

\section{A. Websites Are Not a Place of Public Accommodation}

A website is not a "place of public accommodation" because, even if it falls within one of the twelve "public accommodation" categories, it is not a "place." Still district courts within the First and Seventh Circuits have consistently held that a website is a "place of public accommodation." 166 These courts do not even attempt to interpret the word "place." Instead, like the First and Seventh Circuits, they skate over the existence of the word "place." Along with following the precedents of the First and Seventh Circuits that interpret a "place of public accommodation" to mean a "service of a public accommodation,"

cv-617-WMC, 2020 WL 7768011, at *5 (W.D. Wis. Dec. 30, 2020).

161. Wright, $2021 \mathrm{WL} 243604$, at *2.

162. Id.

163. Id.

164. Id. at *3.

165. Nat'1 Ass'n of the Deaf v. Netflix, Inc., 869 F. Supp. 2d 196, 201 (D. Mass. 2012); Access Now, Inc. v. Blue Apron, LLC, No. 17-cv-116-JL, 2017 WL 5186354, at *3 (D.N.H. Nov. 8, 2017); Wright, 2021 WL 243604, at *2; Laufer, 2020 WL 7768011, at *2-3.

166. Nat'l Ass'n of the Deaf, 869 F. Supp. 2d at 201; Access Now, Inc., 2017 WL 5186354, at*3; Wright, 2021 WL 243604; Laufer, 2020 WL 7768011, at*4. 
these courts rely on the ADA's legislative history and DOJ guidance. ${ }^{167}$ But these secondary sources also lend no support to these courts' holdings that a website is a "place of public accommodation."

\section{Faulty Circuit Court Precedent}

The most common source of support on which district courts within the Minority Approach rely on are the First and Seventh Circuits' holdings in Carparts and Morgan. ${ }^{168}$ As explained above, the First and Seventh Circuits interpret a "place of public accommodation" to mean a "service of public accommodation." 169 As for the word "place," district courts within the Minority Approach have followed the same circuit court precedent that ignores the word "place." 170 For example, the court in National Ass'n of the Deaf stated that "[t]he ADA lists twelve categories of entities that qualify as places of public accommodation." 171 Congress provided twelve categories of entities that qualify as "public accommodations," not "places of public accommodation." 172 The applicable regulations define a "place" as a "facility," which in turn is defined as "all or any portion of buildings, structures, sites, complexes, equipment, rolling stock or other conveyances, roads, walks, passageways, parking lots, or other real or personal property, including the site where the building, property, structure, or equipment is located." 173 Thus, even if Netflix's video streaming website or any other website falls within one of the twelve categories, "the language in question refers to 'facility' which appears clearly to be defined as a physical structure." "174 Yet, the court in National Ass' $n$ of the Deaf, like every other district court applying the Minority

167. Nat'l Ass'n of the Deaf, 869 F. Supp. 2d at 201; Access Now, Inc., 2017 WL 5186354, at*3; Wright, 2021 WL 243604; Laufer, 2020 WL 7768011, at*4.

168. Nat'l Ass'n of the Deaf, 869 F. Supp. $2 \mathrm{~d}$ at 201; Access Now, Inc., $2017 \mathrm{WL}$ 5186354, at*3; Wright, 2021 WL 243604, at*3; Laufer, 2020 WL 7768011, at*23.

169. See supra Part IV.

170. Nat'l Ass'n of the Deaf, 869 F. Supp. 2d at 201; Access Now, Inc., 2017 WL 5186354, at*3; Wright, 2021 WL 243604, at *3; Laufer, 2020 WL 7768011, at*23.

171. Nat'l Ass'n of the Deaf, 869 F. Supp. 2d at 201.

172. 42 U.S.C. § 12181(7).

173. 28 C.F.R. $\S 36.104(2020)$.

174. Brown v. 1995 Tenet ParaAmerica Bicycle Challenge, 959 F. Supp. 496, 498

(N.D. Ill. 1997). 
Approach, conveniently glossed over the word "place" when interpreting a "place of public accommodation."175

In addition, these district courts, like the First and Seventh Circuits, fail to distinguish "places of public accommodation" from "services of a place of public accommodation." 176 For example, in $\mathrm{Na}$ tional Ass'n of the Deaf, the court reasoned that Carparts "applies with equal force to services purchased over the internet, such as video programming offered through the Watch Instantly web site." 177 The court added that "[in] a society in which business is increasingly conducted online, excluding businesses that sell services through the Internet from the ADA . . . severely frustrates Congress's intent . . ." 178 However, Title III regulates services of a "place of public accommodation," not services of any business or "services which the lessor of the public accommodation offers which fall within the scope of Title III." ${ }^{179}$ In National Ass'n of the Deaf, the video streaming website is a service of Netflix, not a service of a place of public accommodation owned, leased, or operated by Netflix. Thus, even if a website is a "service," the text regulates only websites of a "place of public accommodation," not every entity with a website.

\section{Legislative History}

The second most common source relied on by district courts within the Minority Approach is unsurprisingly the ADA's legislative history. ${ }^{180}$ Not only is reliance on legislative history misplaced when determining whether a website is a "place of public accommodation," $" 181$ but the legislative history on which these district courts rely

175. Nat'l Ass'n of the Deaf, 869 F. Supp. 2d at 201; Access Now, Inc., 2017 WL 5186354, at *3; Wright, 2021 WL 243604, at *3; Laufer, 2020 WL 7768011, at *23.

176. Carparts Distrib. Ctr., Inc., 37 F.3d at 18-20; Morgan, 268 F.3d at 459.

177. Nat'l Ass'n of the Deaf, 869 F. Supp. 2d at 201.

178. Nat'l Ass'n of the Deaf, 869 F. Supp. 2d at 200 (citing Carparts Distrib. Ctr., Inc., 37 F.3d at 20).

179. Stoutenborough v. Nat'l Football League, 59 F.3d 580, 583 (6th Cir. 1995).

180. Nat'l Ass' $n$ of the Deaf, 869 F. Supp. 2d at 201; Access Now, Inc., 2017 WL 5186354, at *3; Wright, 2021 WL 243604, at *3; Laufer, 2020 WL 7768011, at *23.

181. Octane Fitness, LLC v. ICON Health \& Fitness, Inc., 134 S. Ct. 1749, 1755 (2014) ("Our analysis begins and ends with the text of [the disputed statute] . . . This text is patently clear."). 
does not support the position that a website is a "place of public accommodation."

As with any issue of statutory interpretation, a court must begin with the words of the statute. ${ }^{182}$ Indeed, the First Circuit in Carparts ironically stated: "We begin our analysis by looking at the language of the statute." 183 Thus, whether a website is a "place of public accommodation" should be determined by the text of the law, not the supposed "purpose" of the law. ${ }^{184}$ Here, the answer is clear. A website is not a "place." Thus, the use of legislative history is unjustified. ${ }^{185}$ But district courts within the Minority Approach refer to the text as "irrelevant" because the supposed "intent" of Congress supports the holding that a website is a "place of public accommodation." ${ }^{186}$ But, "[w]e are a government of laws, not of men, and are governed by what Congress enacted rather than by what it intended." 187 Furthermore, these courts derive the supposed "intent" of Congress from a single House Committee Report. Of pertinence is this quote from Former Associate Justice Antonin Scalia:

My Court is frequently told, in briefs and in oral argument, that 'Congress said thus-and-so' when in fact what is being quoted is not the law promulgated by Congress, nor even any text endorsed by a single house of Congress, but rather the statement of a single committee of a single house, set forth in a committee report. ${ }^{188}$

182. See, e.g., Henson v. Santander Consumer USA Inc., 137 S. Ct. 1718, 1721 (2017) ("[W] e begin, as we must, with a careful examination of the statutory text."); Ross v. Blake, 136 S. Ct. 1850, 1856 (2016) ("Statutory interpretation, as we always say, begins with the text ....").

183. Carparts Distrib. Ctr., Inc., 37 F.3d at 19.

184. Id.

185. NLRB v. SW Gen., Inc., 137 S. Ct. 929, 942 (2017) ("The text is clear, so we need not consider this extra-textual evidence.").

186. Nat'l Ass'n of the Deaf v. Netflix, Inc., 869 F. Supp. 2d 196, 201 (D. Mass. 2012); Access Now, Inc. v. Blue Apron, LLC, No. 17-cv-116-JL, 2017 WL 5186354, at*3 (D.N.H. Nov. 8, 2017); Wright v. Thread Experiment, LLC, No. 19 -cv-01423-TAB, 2021 WL 243604, at*3 (S.D. Ind. Jan. 22, 2021); Laufer v. Lily Pond LLC Series, 2020 WL 7768011, at *2-3 (W.D. Wis. Dec. 30, 2020).

187. Lawson v. FMR LLC, 571 U.S. 429, 459-60 (2014) (Scalia, J., concurring in part and concurring in judgment).

188. AntOnin ScAlia, Common Law Courts in a Civil-Law System: The Role of United States Federal Courts in Interpreting the Constitution and Laws, in A MATter of InTERPRETATION: Federal COURTS AND THE LAW 3, 31 (Amy Gutmann ed., 1997). 
Even if we return to the Church of the Holy Trinity days, when legislative intent trumps the text of the law, ${ }^{189}$ it is still improbable that congressional intent supports the application of Title III to websites because websites did not exist when the ADA was enacted. Yet these district courts rely on a single House Committee Report that states that "the Committee intends that the types of accommodation and services provided to individuals with disabilities, under all of the titles of this bill, should keep pace with the rapidly changing technology of the times." 190 These district courts have interpreted this to mean that Congress intended the "public accommodation" categories to expand in light of technology. ${ }^{191}$ Contrary to these courts' conclusions, the report does not suggest that the "public accommodation" categories should expand in light of technology, only that the types of accommodation and services should adapt with technology. Thus, even the legislative history these district courts rely on does not actually support the position that a website is a "place of public accommodation."

\section{DOJ Guidance}

Another common source district courts within the Minority Approach rely on is an opinion letter from the DOJ. ${ }^{192}$ As mentioned, the DOJ sent a letter to members of Congress addressing the "unresolved questions about the applicability of the ADA to websites."193 In this letter, Assistant Attorney General Stephen E. Boyd wrote:

The Department first articulated its interpretation that [the] ADA applies to public accommodations' websites over 20 years ago. This interpretation is consistent with the ADA's title III requirement that goods, services, privileges, or activities provided by places of public accommodation be equally accessible to people with disabilities. ${ }^{194}$

189. See Church of the Holy Trinity v. United States, 143 U.S. 457 (1892).

190. H.R. REP. No. 101-485(II) at 109 (1990), as reprinted in 1990 U.S.C.C.A.N. $303,391$.

191. Nat'l Ass'n of the Deaf, 869 F. Supp. 2d at 201; Access Now, Inc., 2017 WL 5186354, at*3; Wright, 2021 WL 243604, at *2; Laufer, 2020 WL 7768011, at*3.

192. Nat'l Ass'n of the Deaf, 869 F. Supp. 2d at 199; Access Now, Inc., 2017 WL 5186354, at*5; Wright, 2021 WL 243604, at*2.

193. Letter from Members of Cong. to Jeff Sessions, Att'y Gen. of the U.S., Dep't of Just. (June 20, 2018), https://www.adatitleiii.com/wp-content/uploads/sites/121 /2018/06/ADA-Final-003.pdf [https://perma.cc/8ER3-WXML].

194. Letter from Stephen E. Boyd, Assistant Att'y Gen. of the U.S. Dep't of Just., to Ted Budd, U.S. H.R. (Sept. 25, 2018), https://www.adatitleiii.com/wp-content /uploads/sites/121/2018/10/DOJ-letter-to-congress.pdf [https://perma.cc/W8KA- 
District courts within the Minority Approach have interpreted this statement to mean that the DOJ considers websites a "place of public accommodation." 195 The DOJ's position, however, is not that a website is a "place of public accommodation," but that if a "place of public accommodation" has a website, then the website is subject to liability under Title III. Even if the DOJ had stated in this letter that a website is a "place of public accommodation," the letter is merely a general policy statement, which is not legally binding; it is merely persuasive authority at best. ${ }^{196}$

\section{B. Certain Websites are a "Service," "Privilege," or "Advantage" of a Place of Public Accommodation ${ }^{197}$}

\section{Websites Are a "Service," "Privilege," or "Advantage" for Purposes of Title III}

If websites are not a "place of public accommodation," the question then becomes whether websites are subject to Title III based on a different part of the text. ${ }^{198}$ As stated above, the text concerns the "goods, services, facilities, privileges, advantages, or accommodations of any place of public accommodation." 199 For starters, websites are in some cases a "good" of an entity but are not a "good" of a "place of public accommodation." 200 Websites are also not a "facility," which is defined as "all or any portion of buildings, structures, sites, complexes, equipment, rolling stock or other conveyances, roads, walks, passageways, parking lots, or other real or personal property, including the site where the building, property, structure, or equipment is

KNJM].

195. Nat'l Ass' $n$ of the Deaf, 869 F. Supp. 2d at 199; Access Now, Inc., 2017 WL 5186354, at*3; Wright, 2021 WL 243604, at *2.

196. See Unwired Planet, LLC v. Google Inc., 841 F.3d 1376, 1381 (Fed. Cir. 2016).

197. This Comment does not address the "intangible barrier" concept mentioned in Gil v. Winn-Dixie Stores, Inc., 993 F.3d 1266, 1277 (11th Cir. 2021), because the concept concerns whether a website discriminates or not, and this Comment is solely limited to whether a website is subject to Title III.

198. Gil v. Winn-Dixie Stores, Inc., 993 F.3d 1266, 1274 (11th Cir. 2021).

199. 42 U.S.C. $\S 12182(a)$.

200. Stoutenborough v. Nat' 1 Football League, Inc., 59 F.3d 580, 583 (6th Cir. 1995). 
located."201 But some websites are a "service," "privilege," or "advantage" of a "place of public accommodation."

The ADA does not define these terms. In such cases, courts look to the word's plain meaning at the time of enactment. ${ }^{202}$ In the context of website accessibility lawsuits, the dissent in Gil was the first to do so and used the dictionary definitions present when the ADA was passed:

The dictionary definition of "service" is "useful labor that does not produce a tangible commodity." Service, Webster's New International Dictionary (3d ed. 1961). A "privilege" is "a right ... granted as a peculiar benefit, advantage, or favor." Privilege, Webster's New International Dictionary (3d ed. 1961). And an "advantage" is "a more favorable or improved position or condition." Advantage, Webster's New International Dictionary (3d ed. 1961). ${ }^{203}$

Under these definitions, the dissent concluded that WinnDixie's website was a "service," "privilege," and "advantage" of its physical stores because it allowed customers to refill prescriptions and link coupons to their rewards cards. ${ }^{204}$ The majority opinion disagreed and stated that under the dissent's interpretation "virtually anything ... might be deemed a 'service,' 'privilege,' or 'advantage' for the purpose of Title III." ${ }^{205}$ The majority opinion did not dispute the dissent's definitions of these terms, state its interpretation of these words, or justify its departure from the letter of the law. ${ }^{206}$ Instead of "giv[ing] effect, if possible, to every clause and word" of Title III, ${ }^{207}$ the court ignored those terms and considered only whether a website is a "place of public accommodation." 208

Even if the dissent's interpretation is too broad, "virtually anything . . might be deemed a 'service,' 'privilege,' or 'advantage"" under the narrowest interpretations of those terms. The majority opinion may not agree with Congress's decision to include such broad

201. 28 C.F.R. $\S 36.104$ (2020).

202. Tanzin v. Tanvir, 141 S. Ct. 486, 491 (2020); FCC v. AT\&T Inc., 562 U.S. 397, 403 (2011).

203. Gil, 993 F.3d at 1294.

204. Id.

205. Id. at 1281.

206. See id. at 1281-84.

207. Duncan v. Walker, 533 U.S. 167, 174 (2001) (quoting United States v. Menasche, 348 U.S. 528, 538-39 (1955)).

208. Gil, 993 F.3d at 1266. 
terms, but as Justice Scalia has noted, "Congress can enact foolish statutes as well as wise ones, and it is not for the courts to decide which is which and rewrite the former." ${ }^{209}$ In essence, the majority opinion rewrote Title III to include only the words "place of public accommodation." But Title III also includes the words "service," "privilege," and "advantage." And for purposes of Title III, websites are a "service," "privilege," or "advantage" under the plain meaning of those terms.

\section{Only Websites “Of” a Place of Public Accommodation Should be Subject to Title III}

While websites are a "service," "privilege," or "advantage" for purposes of Title III, only websites "of" a "place of public accommodation" are subject to Title III. Courts applying the Nexus Test have interpreted the word "of" to mean a connection or nexus. ${ }^{210}$ Other courts, however, have failed to understand the textual basis for the Nexus Test. For example, the majority and dissent in Gil agreed that there was "no basis for it in the statute or in our precedent." ${ }^{211}$ But as mentioned, the word "of" is the statutory support for the Nexus Test. A court may interpret the word "of" differently, but there is a clear textual basis for the Nexus Test.

While the Ninth Circuit and Eleventh Circuits in Robles and Haynes applied the Nexus Test to websites, several questions arise from these courts' holdings. The first question that arises is what kinds of websites are "of" a "place of public accommodation." The Ninth and Eleventh Circuits held that websites that include things such as a store locator or the option to purchase gift cards are "of" a "place of public accommodation." ${ }^{212}$ But courts are likely to vary depending on the facts present and the various interpretations of the word "of." The second question that arises is whether the entire website is subject to Title III or only the portions of the website that establish the connection. For example, if a website has a store locator or an option to

209. Antonin SCAliA, Common Law Courts in a Civil-Law System: The Role of United States Federal Courts in Interpreting the Constitution and Laws, in A MATtER OF InTERPRETATION: FEDERAL COURTS AND THE LAW 3, 20 (Amy Gutmann ed., 1997).

210. See Gil, 993 F.3d at 1266.

211. Id. at 1281.

212. Robles v. Domino's Pizza, LLC, 913 F.3d 898, 905-06 (9th Cir. 2019); Haynes v. Dunkin’ Donuts LLC, 741 F. App’x 752, 753-54 (11th Cir. 2018). 
purchase gift cards, is any other feature of the website subject to the ADA. That said, if courts are going to faithfully apply the text of Title III to websites, the differences between courts should not be based on whether a website is a "place of public accommodation," or whether a website is a "service," "privilege," or "advantage" of a "place of public accommodation." Rather, the differences should be based on whether a website is "of" a "place of public accommodation."

\section{CONCLUSION}

The first requirement to deciding whether a website is subject to Title III is determining whether the entity has a "place of public accommodation." The entity's operations must fall within one of the twelve "public accommodation" categories. In turn, those operations must be those of a "place." For example, Netflix video streaming services would fall within one of the twelve "public accommodation" categories but would not be a "place of public accommodation" because it is not a "place." In contrast, a movie theater would be a "place of public accommodation" because its services fall within the twelve "public accommodation" categories and is a "place."

The second requirement is determining whether the website is "of" the "place of public accommodation." While websites are "services," "privileges," and "advantages" for purposes of Title III, the website must be "of" the "place of public accommodation" to be subject to Title III. Websites that are merely "of" the entity are not subject to Title III. For example, Netflix's website is a service, privilege, and advantage "of" the entity rather than "of" any "place of public accommodation." Furthermore, the fact that an entity has both a website and a "place of public accommodation" does not necessarily establish liability under Title III. The website must be "of" a "place of public accommodation." 